\title{
JUDICIAL DISCRETION IN PATENT CAUSES
}

The Preacher is not called to account for his words. He takes refuge behind a text. With a good text he may deal fearlessly with most delicate questions.

I have the desire to speak concerning a most delicate subjectthe subject of judicial discretion as it finds expression in the law of patents. We may dissect or criticise the product of the judicial mind in perfect freedom; but when we attempt to discuss the motive, the moral consciousness, back of the product we must proceed with caution. So it has occurred to me that, with a good text, I might preach a sermon devoid of offense.

While my text is so old that the memory of man runneth not to the contrary, I have no doubt that the memory of man has taken liberties with the original pronouncement. In fact I find myself compelled to go down into the paleozoic stratum of my memory to find the text, which stratum of sand and silt of textbook law was deposited during student days.

My text is: "Judicial discretion depends upon the length of the chancellor's boot."

First, then, we come directly to the Selden Case. ${ }^{1}$

No one can read these opinions without being convinced that Selden conceived (and disclosed in his patent application) the generic idea of propelling a wheeled vehicle by a gas-engine. Selden is an able patent lawyer, a son of one of the greatest patent lawyers of a former generation, a man with Yale training; and he drew his claims to cover clearly and absolutely all types of gas-engine propelled wheel-carriages. ${ }^{2}$

The trial court found that, notwithstanding the fact that Selden had coddled his application in the Patent Office for nearly the

${ }^{3}$ Columbia v. Duerr, 185 Fed. 893, 107 C. C. A. 215, reversing I72 Fed. 93I.

The main claim of the Selden patent reads:

"The combination with a road locomotive, provided with suitable running gear including a propelling wheel and steering mechanism, of a liquid hydro-carbon gas engine of the compression type, comprising one or more power cylinders, a suitable liquid fuel receptacle, a power shaft connected with and arranged to run faster than the propelling wheel, an intermediate clutch or disconnecting device and a suitable carriage body adapted to the conveyance of persons or goods, substantially as described." 
I7-year period which is the life-limit of a patent, he had kept strictly within the statute, and having done so, his patent was good. Whatever the personal feelings of the trial judge may have been, he decided the case on the facts and the law. The chancellorial boot was quiescent.

But by the time the case reached the appellate tribunal that thing which we sometimes call public opinion and which, once dynamic in the judicial mind, not infrequently becomes the highest type of judicial discretion, had reached a degree where it was felt that the Selden monopoly-then a corporate monopoly-was unmoral if not immoral. Then, too, the chancellor's boot grows in length as it proceeds upwardly to appellate jurisdiction; and it is well that it does and becomes a better measure.

The opinion of the trial judge in this case was masterful; why set it at naught? From an unconscionable record filling $3^{6}$ octavo volumes he had gathered the facts and applied the law in perfect clearness; what ground was there for reversal?

It is true that Selden made application for his patent in 1879 , that he kept it in the Patent Office until 1895, and thus practically extended his monopoly over a period of 33 years from his filing date. And it is true that, so far as advancing the automobile art, Selden slumbered all those years, and that in the meantime others had reinvented the gas-engine propelled vehicle and carried the art to practical ends. And when the highways had become full of automobiles Selden set up his toll-gate.

But Selden knew, or might have known, that the Berliner telephone patent application was filed in 1877 , and that the Bell Telephone Company coddled that application in the Patent Office until about the time the generic Bell patent expired, and then, in r891, more than fourteen years after filing, took out the Berliner patent and thereby extended the Bell monopoly to cover a period of some 33 years. He knew that the Supreme Court had upheld this Bell monopoly. ${ }^{3}$ And who shall say that he was not justified in thinking he might set up his toll-gate and take the small coin of automobilist, a tax on luxuries, when the Supreme Court permitted the Bell monopoly to tax the all-necessary telephone for 33 years?

Under the hypnotic spell of Joseph $\mathrm{H}$. Choate and Frederick $P$. Fish the judicial discretion of the Supreme Court gave place

'United States v. Am. Bell Tel. Co., I67 U. S. 224, 42 L. ed. I44, 17 Sup. Ct. 809. 
to judicial literalism, and the Bell company held its unmoral monopoly for almost double the life of the generic Bell patent.

But the years passed, and Frederick P. Fish endeavored to cast the same spell that had worked so well some fifteen years before in the Berliner Case. Though backed by some of the most able counsel, the charm failed; the Circuit Court of Appeals was not a hypnotic subject, and the Selden monopoly fell.

How wide open the door to the Supreme Court for the exercise of judicial discretion in the Berliner Case one may see from the facts. Not only had the Berliner application been kept in cold storage in the Patent Office over fourteen years, but it had been "divided," and one part issued as a patent eleven years previously; and it was also an open question whether the claims of the final monopoly had not been injected long after two-year public use and that, consequently, no patentable subject-matter remained.

How narrow a crack sufficed for the Circuit Court of Appeals in the Selden Case may also be seen. The court-do the best it might-could not hold the patent void, but squeaked through the narrow crack of finding non-infringement. Notwithstanding the fact that Selden's claim called for an engine of "the compression type," without any limitation to any specific type, it was held to be limited to an external compression engine of the Brayton type, and not to include an internal compression engine of the Otto type, which, of course, is the type of engine employed in all gas-engine propelled vehicles.

Now, the fact which these two cases make plain is that the chancellor's boot has grown longer with the years; and despite the pessimists and those judicial reformers who would establish a sort of political spanking-machine for dealing with our judges, it is a fact that judicial discretion has grown, in some degree at least, in step with our industrial progress and advancement toward a more perfect justice, to the end that our complex problems may not, by sheer complexity, get beyond the reach of the chancellorial boot.

However one may view the facts in these two cases, the truth remains that the decision of the Supreme Court in the Berliner Case could be repeated to-day no more than the decision in the Dred Scott Case. No matter if the logic of the Circuit Court of Appeals does appear strained in the light of the cases, it resulted in the exercise of judicial discretion which was justice rather than academic law. 
But someone may ask, whither does this tendency lead, what are its limits? Is not the decision of the Supreme Court in the Mimeograph Case ${ }^{4}$ as reactionary as the Berliner Case? Let us see.

The principles of the Mimeograph Case were settled long ago by three great judges, one of whom became President of the United States and another a Justice of the Supreme Court.5 The only reason why the rule so clearly stated in the Button Fastener Case, supra, has been attacked in vigorous terms by a dissenting minority of the Supreme Court is because there is a quickened public conscience which manifested itself in judicial discretion in the Selden Case to stop unmoral monopoly by abuse of the patent monopoly, and which would extend that power unduly.

And here is marked the limit of the legitimate extension of that power. I repeat that the decision of the Mimeograph Case was sound. It was a decision upholding the plain purpose of the statute as against popular demand for its overthrow growing out of the abuse of the real purpose of that statute. It marks the limit of judicial discretion. We must not make the mistake of thinking the chancellor's boot has grown so great a power that it may eliminate a statute because, with the passing of time and change of condition, abuses have grown up which could not have been foreseen by the legislative power at the time of enactment. The remedy is in a revision of the statute, and not in undue exercise of judicial discretion. The public interest in the questions raised by the Selden Case and the Mimeograph Case has resulted in the so-called Oldfield Bill now before the Congress, which, properly considered and amended, should render unnecessary judicial straining of fact and law, as in the Selden Case, or the rendition of a decision in conformity to statute but out of step with public opinion, as in the Mimeograph Case. ${ }^{6}$

\footnotetext{
'Henry v. Dick, 224 U. S. I, 56 L. ed. 645, 32 Sup. Ct. 364.

${ }^{5}$ Heaton v. Eureka, 77 Fed. 288, 25 C. C. A. 267.

'The Oldfield Bill now before the Congress contains the following general provisions:

First, substantially limiting the life of every patent to Ig years from the filing date and to not more than I7 years from the issue date.

Second, substantially defeating by limiting liability for infringement the monopoly restriction in sale or use of patented articles, such as has grown up under the Button Fastener Case, the Mimeograph Case, and the much broader and much more questionable decision of the Supreme Court in the Harrow Case (Bement v. National Harroze Co., I86 U. S. 70, 46 L. ed. 1058, 22 Sup. Ct. 747).
} 
My secondly may also be illustrated by the Selden Case. It is, of course, the rule that the courts cannot expand a patent claim unduly ${ }^{\tau}$ and it is also the rule that the courts cannot disregard an element positively included in the claim. ${ }^{8}$ While in dealing with a generic invention the courts adopt a liberal view of the claim $^{9}$ they practically reverse this view in the case of a narrow improvement. ${ }^{10}$ Sound rules like these mark the four corners of judicial liberty and liberality upon the broad principles that a patent is a monopoly created under statute in contravention of common-law right and that the courts cannot rewrite a statute; but within these four corners there is much room for the exercise of judicial discretion.

With such rules as these in view let us suppose that Selden, instead of suppressing his invention in the Patent Office, had taken out his patent promptly, used it, and made large contribution to the automobile art. And suppose that in drawing his claims he had included some essential element only by implication or had, without having been obliged so to do to secure his claim, included some unimportant, non-essential feature,--it being assumed, of course, that his drawings and specification fully disclosed his actual invention. In such case would the Selden patent have been held valid and infringed? Under the old, strict-construction rules it is probable that the claim would have failed; but under the broader vision of the courts ${ }^{x x}$ it is probable that, in the hands of a wise chancellor, the claim would have prevailed.

Hence the point: In judicial claim-construction literalism not infrequently defeats the very end of justice; while the wise exercise of judicial discretion preserves. For just as in receiv-

Third, a compulsory license provision similar to that in force many years in several foreign countries, and which, if it had been enacted years ago, as it should have been, would to-day relieve this country from the German chemical monopoly which is hampering our industries while Germany is at war.

Fourth, bringing foreign owners of United States patents under the jurisdiction of the United States courts as to such patents, regardless of their place of actual residence.

${ }^{7}$ Woolensak v. Sargent, I5I U. S. 221, 38 L. ed. I37, I4 Sup. Ct. 291.

${ }^{8}$ Keystone v. Phoenix, 95 U. S. 274, 24 L. ed. 344.

'Sessions v. Romadka, I45 U. S. 29, 36 L. ed. 609, I2 Sup. Ct. 799.

${ }^{10}$ McCarty v. Lehigh, 160 U. S. I10, 40 L. ed. 358, I6 Sup. Ct. 240.

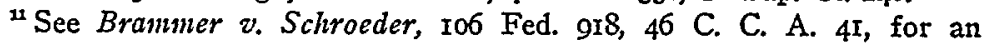
example. 
ing a message over the telephone-where you rarely, if ever hear every word or detail of a statement, but combine with the word-symbols mechanically conveyed to your own apperception of the matter,- - so it is with even a written statement such as a patent claim. You get the true meaning in the mind of the patentee only as to the written word you add your own grasp of the mind-content back of the written word.

Thus it becomes of the utmost importance that the judicial mind should be unhampered either by statute drawn to invade the domain of high moral discretion, or by arbitrary case-rule which aims to a like end; but on the other hand, as I shall urge later, the exercise of such wide power should be tethered by appellate review of both fact and law,-not to defeat or limit it, but to make certain that mistake in either fact or law has not been made.

My thirdly is pragmatism. Judicial discretion in patent causes not infrequently is the philosophy of William James. I have endeavored to show by comparison of the Selden Case with the Berliner Case that, once face to face with an unmoral situation, the literalism of a past generation gives place to the higher morals of the law.

And I am not unaware that the critical reader may say that what I am calling "judicial discretion" or "pragmatism" are both wide of the dictionary. I will not argue the question beyond this: To do equity is a generalization; to weigh a specific situation wherein the chancellor must mete out justice and must steer his course past statute and appellate rule and not run amuck, wherein he must obey the statute not only in spirit but in letter sufficiently that his decision may stand, wherein he must construe and distinguish case-law in a manner not to confound precedent-all this requires the exercise of a discretion, a vision, that is at once telescopic and microscopic, a discretion that not infrequently involves the genius to read an old statute in the light of new economic and industrial condition, all entirely beyond the judicial function of hearing the plaint and reply of two men and finding the simple equities in the case. And in no branch of the law are these problems more frequently present or more frequently confoundingly complex than in the law of patents. It is because a quickened public conscience demands this judicial genius and because some judges have failed in its application-fallen back upon the easy cushion of restful strict construction of statute and application of case-that a demand for 
judicial recall and recall of judicial decision has been propounded as a remedy-a remedy that is nothing short of amputation of the arm of the law to cure a run-around on a judicial finger.

But to come back to my thirdly. The Congress which enacted the basic provision of the patent statute said ( $\$ 4886)$ :

"Any person who has invented or discovered any new and useful art, machine, manufacture, or composition of matter, or any new and useful improvements thereof .......may........ obtain a patent therefor."

The italics are mine. The words "and useful" are those which are moving our patent courts to a wiser and better dispensation.

But to digress for a moment (and the preacher may do so where the lawyer may not), it is the strange fact that, in all the years we have had a patent office granting patents under this specific condition-precedent statute, there has never been the slightest obedience to the requirement that inventions must be found useful. Patents are being granted at the rate of approximately 50,000 a year. It is notorious that not one in ten of this vast number adds one iota to the utilities of life. Not only is it the fact that the Patent Office pays no heed to the requirement of utility, but it is also true that when one attempts to distinguish an invention from a prior patent by showing that the invention is operative and useful while the prior patent cited by the examiner as anticipatory is wholly inoperative and consequently not useful, he fails to make the slightest impression upon the Patent Office intellect. This is too large a subject for consideration here. I am merely calling attention to the fact that all these years the Patent Office has been disobeying the statute, and that the time must come when some leader large and strong enough to overcome the inertia of Congress will attack this national evil and make our Patent Office the great and beneficent institution it should be. But to return.

Take this case: The complainant charges infringement of an improvement patent. The defendant attacks the patent by showing from the prior art that, if the complainant has taken any step at all, his advance closely borders mere mechanical skill. $\mathrm{He}$ puts the novelty of the invention clearly in doubt. Seemingly only the prima facie of the grant can save the patent; and that method of resuscitating a comatose patent practically ended with the passing-on of Judge Hall many years ago. The scales are at 
equilibrium. What shall turn them? The complainant shows that his invention works, that it has gone into general, practical use; he shows that the prior patents cited have not. He wins.

Take another case: This patent is also for a seemingly narrow improvement. It is useful, but unlike the former case, the prior patents also have been useful. Judged merely from the paper showing, the novelty is put in limbo. What shall turn the scales? The complainant shows that, instead of using any one of prior devices which the defendant alleges to be anticipatory and some of which were open to his use because the patents had expired, he has deliberately made a Chinese copy of the invention of complainant's patent. By such act the defendant has confessed the utility of the invention, and by such act has confessed a preferable utility over prior devices. Again the complainant wins.

From the time of the Barbed Wire Case ${ }^{12}$ to the Collar Button Case $^{13}$ and on down to the Rubber Tire Case ${ }^{14}$ there has been a growing tendency to make utility the test where the question hangs in the balance. Slight as was the change in the Barbed Wire Case, it turned failure into success. Simple as was the one-piece collar button, it found large commercial use. Although the rubber tire improvement was almost indefinable, it was extensively used and extensively infringed by absolute copying.

Turning to my notes $I$ find that, without instancing the numerous cases where the trial courts have applied these rules, the appellate courts have held commercial success the determining factor in ten doubtful cases; in fourteen instances the efficiency of the device turned the scale in its favor; in twenty-seven cases extensive use has persuaded; in twenty-eight suits the proof of prior failures sufficed; in twelve cases the courts expressed the reason for upholding the patent as turning failure into success; in forty-six cases the broad term utility was deemed sufficient to cover the ruling; in seventeen cases use by defendant and in six cases extensive litigation due to extensive infringement were moving factors.

Of course, such rules are often urged by counsel where they do not apply-where they are insufficient to counterbalance other factors,- and the courts have had to make it very plain that these

${ }^{12}$ I43 U. S. 275,36 L. ed. I54, I2 Sup. Ct. 443.

${ }^{13}$ I48 U. S. 556,37 L. ed. 558, I3 Sup. Ct. 719.

${ }^{14} 220$ U. S. 428,55 L. ed. 527,3 I Sup. Ct. 444. 
rules cannot apply in the absence of patentable novelty, or in cases where other factors have right of way.

However, the application of pragmatism to patents, with proper discrimination, is becoming a ready rule by which our judges solve every-day problems of doubtful novelty. It is a good rule, but, like every good rule, is capable of abuse. It must not be applied, for example, to negative novelty in a case where the invention has failed of large use where reasons of time or circumstance may have prevented such use; nor must it be applied where the commercial success has been due to extensive advertising or commercial genius of the owner. I could name a patent which has earned its owners hundreds of thousands in the past twenty years, which has been advertised in women's magazines, on bill-boards and in street-cars all over the land; but which was, in fact, invented and patented in England away back in the fifties. Here the success was due to the genius of a great advertiser in the exploitation of a patent wholly without novelty.

But a sermon which does not depict some sin or attack some evil is lacking in dynamics; and so in my fourthly I wish to call attention to what $I$ regard as a most dangerous menace to the proper exercise and safeguarding of judicial discretion.

It is an established rule that, where a patent cause has been tried on the law side of the court, the appellate tribunal will not review the facts except in the case of manifest error. This is but the application of the general and familiar rule to patent causes; but if one goes through the patent causes tried on the law side and reviewed on appeal, it will be found that even in law actions the appellate courts have not hesitated to review the facts to the end that one is forbidden to say that this rule is absolute. It is far from absolute, even where no glaring error has been committed at the trial; and this is as it should be.

But in patent causes tried on the equity side of the court there have come into existence such appellate rulings as the following:

These concurring findings (of the master and the circuit court) are presumptively correct and must be permitted to stand, unless some obvious error has intervened in the application of the law, or some serious and important mistake has been made in the consideration of the evidence.-Brown v. Lanyon, 179 Fed. 309, 102 C. C. A. 497 (Eighth Circuit, Judge-now Mr. Justice-Van Devanter writing the opinion).

The testimony of the witnesses upon this issue is conflicting and under a familar rule the finding of the chan- 
cellor must prevail unless the defendant has succeeded in showing from the record that he has made a mistake in his deduction of this fact from the evidence.-Century Electric Co. v. Westinghouse, I9I Fed. 350, II2 C. C. A. 8 (Eighth Circuit, Judge Sanborn writing the opinion). The question of infringement being one of fact, we might be justified in following, in the absence of manifest error, the finding of the court below.-Krupp v. Midvale, r91 Fed. 588, r12 C. C. A. I94 (Third Circuit, Judge Buffington writing the opinion).

When the chancellor has considered conflicting evidence and made his finding and decree thereon, they must be taken to be presumptively right; and unless an obvious error has intervened in the application of the law, or some serious mistake has been made in the construction of the evidence, they must be permitted to stand.-De Laval $v$. Iowa, I94 Fed. 423 , II4 C. C. A. 385 (Eighth Circuit, Judge Sanborn writing the opinion).

I have given the names of the opinion writers in these cases to show that this rule is being expressed by most able judges; and curiously enough, Judge Sanborn, who wrote two of these opinions-one of our very great patent judges-also wrote the opinion in Brammer $v$. Schroeder, supra, where he exercised most wisely his chancellorial discretion.

Compare these rulings of the Third and Eighth Circuits with the rule of the Second Circuit stated by Judge Lacombe in Transit Development Co. v. Cheatham, I94 Fed. 963, II4 C. C. A. 599:

When questions of fact are disposed of by the trier of the facts in an equity suit, his decisions may be reviewed on appeal. When disposed of by the verdict of a jury, properly instructed, its decision on those points is not reviewable by the appellate court.

It may be said, of course, that there is no real conflict of decision here; that no one of these cases holds that a cause coming up on appeal from the equity side of the court will be denied consideration of the question whether or not manifest error in fact has been committed. But note these facts:

First, notwithstanding the statement of Judge Buffington above quoted that the question of infringement is one of fact, and there is abundant authority for such statement, as a matter of ultimate truth, in many infringement cases, it is not possible to segregate the law and the facts. 
Second, nearly every patent cause vigorously contested and appealed involves, in some form or other, a question of fact that is exceedingly close and difficult of decision.

Third, with the wider, wiser, broader exercise of judicial discretion, the liability of chancellorial error in questions of fact increases directly.

Generally speaking, a close and well-contested case reaches a state by the time it is ready for argument where either attorney could make a most persuasive argument on either side. The story of General Butler is familiar. He had argued a case before the Supreme Court, and it was clear from the assenting nods of the Chief Justice that the court was with him. A few days later he appeared before that court in another case wherein he presented the same question from the other side with equal force. The Chief Justice interrupted him with, "General Butler, did you not argue this identical proposition before this court recently?" The reply was, "I had the honor." Then the Chief Justice inquired severely, "By what show of reason, General Butler, can you submit the proposition in one aspect one day and in the reverse aspect the next?" The answer was ready: "Your Honor, because the great Supreme Court of the United States was mistaken yesterday is no reason why that great court should be mistaken to-day."

The trial judge is beset with (I) inseparable condition of law and fact; (2) close and difficult questions of fact; (3) the necessity of carefully-balanced exercise of judicial discretion. Between the solution of these problems which the trial judge can not escape and the final disposition of every patent cause in equity by the appellate court should stand the review of both law and fact by the appellate court; and the rule should not be merely permissive, but mandatory.

Suppose the rule of the Third and Eighth Circuits, above stated, had been applied in the Selden Case: The patent would have been held valid and infringed, and the man who had added no whit to the practical development of the automobile art, but had concealed his invention in the Patent Office for years would have taken toll from every automobile builder in the United States who had not already paid toll; and very likely would have wrecked more than one man who had borne the brunt of the struggle to bring to practical use the gas-engine-propelled vehicle of to-day. Judicial discretion-that which is higher than the perfunctory fitting a case to the law or the law to a case-meted out justice by reviewing the facts as well as the law. 
Hence my fourthly stands guard over my firstly, secondly and thirdly. In the exercise of judicial discretion by the chancellor broadened as it should be, we must repudiate with all vigor the proposition that the appellate courts shall be relieved from review of the facts, and insist that such review shall be mandatory in patent causes arising on the equity side.

In conclusion, all that has been said, as is the case with most sermons, may be summed up briefly, if only the preacher will. In my firstly I have endeavored to show how our courts are coming to exercise a wider and wiser discretion in patent causes in the difficult task of disposing of an unmoral condition which might remain unreached by legal literalism. In my secondly I have shown how broader wisdom is coming to be applied in claim-construction. In my thirdly I have shown how the philosophy of pragmatism has come to use in turning the scale in the right direction in doubtful cases. In my fourthly I have sounded a warning against a new rule which either may eventuate in making chancellorial discretion a dangerous thing broadly applied, or eventuate in circumscribing its exercise to the great detriment of both inventor and manufacturer.

As the chancellor used to stand by the chancel-bar between people and court, respected by the court and esteemed by the people, so he should stand to-day. His powers have grown as they should, and it is our business-we lawyers who sit just below the chancellor-to preserve inviolate his powers.

Let us pray for deliverance from hampering statute or unwise appellate ruling. Let us have for the chancellor and his powers that high regard which lifts him above the laity and clothes him with authority and distinction which, in turn, engenders in the judicial consciousness an ideal, an impelling course of conduct, as distinct from the greed and struggle of life as is the ideal and conduct of the true priest of the church.

In this hour when the institutions of the Old World are being shaken with shot and shell, the institutions of the New World stand firm. Judicial character, judicial morality, judicial discretion are of the bed-rock upon which we have builded. Let the foundations remain strong.

Here endeth my sermon.

War. Macomber.

BufFalo, N. Y. 